\title{
ANALISA EFISIENSI PEMBUATAN ETHANOL DARI BAHAN BAKU SHORGUM MENGGUNAKAN DISTILATOR REFLUK BERTINGKAT
}

\author{
Rochmad Winarso \\ Fakultas Teknik, Program Studi Teknik Mesin \\ Universitas Muria Kudus \\ Email: rochmad.winarso@umk.ac.id \\ Noor Yulita Dwi Setyaningsih \\ Fakultas Teknik, Program Studi Teknik Elektro \\ Universitas Muria Kudus \\ Email: noor.yulita@umk.ac.id \\ Imam Abdul Rozaq \\ Fakultas Teknik, Program Studi Teknik Elektro \\ Universitas Muria Kudus \\ Email: imam.rozaq@umk.ac.id
}

\begin{abstract}
ABSTRAK
Isu utama di bidang penyediaan energi adalah semakin menipisnya cadangan energi yang bersumber dari perut bumi namun sebaliknya tingkat konsumsi energi justru semakin meningkat. Permasalahan energi saat ini bukan lagi masalah suatu negara tetapi telah menjadi permasalahan global. Proses pengembangan bioethanol di Indonesia saat ini belum dapat memenuhi target tersebut. Beberapa kendala diantaranya adalah pasokan bahan baku yang belum lancar, penguasaan teknologi pengolahan yang kurang efisien dan gangguan lingkungan akibat limbah. Rencana kerja dari kegiatan ini adalah untuk mengetahui tingkat efisiensi sorghum sebagai bahan baku pembuatan bioethanol dan mengetahui pengaruh perubahan lama fermentasi terhadap kadar dan volume bioethanol yang dihasilkan. Untuk mengetahui semua itu pertama yang dilakukan adalah pemilihan bahan baku yang baik, kemudian proses fermentasi yang selanjutnya dilakukan distilasi dan proses akhir adalah dehidrasi. Hasil penelitian menunjukkan bahwa alat bekerja dengan baik, dimana bahan baku shorgum dapat menghasilkan kadar ethanol. Kadar ethanol yang dihasilkan dipengaruhi oleh lamanya waktu destilasi. Dimana saat waktu yang digunakan 30 menit, kadar ethanol yang dihasilkan sebesar 85\% dengan volume hasil ethanol yang dihasilkan kisaran $667 \mathrm{ml}$ untuk jenis shorgum merah. Sedangkan untuk jenis shorgum putih dengan waktu destilasi yang sama didapatkan hasil bahwa kadar ethanol yang dihasilkan sebesar $83 \%$ dengan volume hasil ethanol kisaran 510ml. Sehingga dapat dikatakan bahan baku shorgum merah lebih baik dibandingkan dengan bahan baku shorgum putih.
\end{abstract}

Kata kunci: efisiensi; shorgum; ethanol; distilator.

\begin{abstract}
The main issue in the field of energy supply is the depletion of energy reserves sourced from the bowels of the earth but on the contrary the level of energy consumption actually increases. Current energy problems are no longer a problem of a country but have become global problems. The process of developing bioethanol in Indonesia is currently unable to meet these targets. Some constraints include the supply of raw materials that have not been smooth, mastering less efficient processing technology and environmental disturbances due to waste. The work plan of this activity is to determine the efficiency level of sorghum as a raw material for making bioethanol and determine the effect of changes in the length of fermentation on the levels and volumes of bioethanol produced. To find out all of this, the first thing to do is to choose a good raw material, then the fermentation process which is then distilled and the final process is dehydrated. The results showed that the tool works well, where raw materials of shorgum can produce ethanol levels. The ethanol content produced is influenced by the length of distillation time. Where when the time used is 30 minutes, the ethanol content produced is $85 \%$ with the volume of ethanol produced in the range of $667 \mathrm{ml}$ for the type of red shorgum. While for the type of white shorgum with the same distillation time it was found that the ethanol content produced was $83 \%$ with the volume of ethanol produced in the range of $510 \mathrm{ml}$. So that it can be said that the raw material of red shorgum is better than the raw material of white shorgum.
\end{abstract}

Keywords: efficiency; shorgum; ethanol; distilator. 


\section{PENDAHULUAN}

Isu utama di bidang penyediaan energi adalah semakin menipisnya cadangan energi yang bersumber dari perut bumi namun sebaliknya tingkat konsumsi energi justru semakin meningkat. Permasalahan energi saat ini bukan lagi masalah suatu negara tetapi telah menjadi permasalahan global. Dari tahun ke tahun kebutuhan energi semakin meningkat, walaupun laju pertumbuhan penduduk mengalami penurunan, namun dengan adanya pertumbuhan PDB yang meningkat menyebabkan kebutuhan Energi di Indonesia juga meningkat. Peningkatan kebutuhan energi tersebut diperkirakan mengalami kenaikan rata rata sebesar 4,8\% untuk periode tahun 2000 sampai tahun 2035. Kebutuhan energi di Jawa mengalami pertumbuhan tertinggi sekitar 5,1\% dan Sumatra yang terkecil sekitar 4,5\%. Mengenai pangsa kebutuhan energi, Jawa mempunyai pangsa terbesar sekitar 50\% sedangkan pangsa terkecil ada pada Kalimantan, sekitar 8\%. Jika dilihat menurut sektor, sektor transportasi tumbuh paling tinggi. Seiring dengan meningkatnya PDB, kebutuhan akan transportasi juga semakin tinggi [1].

Energi baru dan terbarukan harus terus dikembangkan karena sumber energi tersebut yang nantinya dapat menopang kebutuhan energi nasional. Beberapa ancaman serius bila masih ada ketergantungan dari energi perut bumi adalah (1) Menipisnya cadangan minyak bumi yang diketahui (bila tanpa temuan sumur minyak baru). (2) Kenaikan atau ketidakstabilan harga akibat laju permintaan yang lebih besar dari produksi minyak dan (3) Polusi gas rumah kaca (terutama CO2) akibat pembakaran bahan bakar fosil [2].

Proses pengembangan bioethanol di Indonesia saat ini belum dapat memenuhi target tersebut. Beberapa kendala diantaranya adalah pasokan bahan baku yang belum lancar, penguasaan teknologi pengolahan yang kurang efisien dan gangguan lingkungan akibat limbah. Bioetanol $(\mathrm{C} 2 \mathrm{H} 5 \mathrm{OH})$ merupakan salah satu biofuel yang hadir sebagai bahan bakal alternatif yang ramah lingkungan dan sifatnya yang terbarukan. Bioetanol dapat diproduksi dari berbagai bahan baku yang banyak terdapat di Indonesia, sehingga sangat potensial untuk diolah dan dikembangkan karena bahan bakunya sangat dikenal masyarakat. Tumbuhan yang potensial untuk menghasilkan bioetanol antara lain tanaman yang memiliki kadar karbohidrat tinggi, seperti: tebu, nira, aren, sorgum, ubi kayu, jambu mete (limbah jambu mete), garut, batang pisang, ubi jalar, jagung, bonggol jagung, jerami dan bagas [3].

Salah satu komuditas yang potensial untuk dikembangkan di Indonesia adalah tanaman sorghum. Menurut [4], Tanaman sorgum ini dapat tumbuh hampir di setiap jenis tanah. Ketahanan terhadap kondisi kering pada tanaman sorgum disebabkan karena adanya lapisan lilin pada batang dan daunnya yang dapat mengurangi kehilangan air karena penguapan. Potensi yang dimiliki tanaman sorgum dapat digunakan sebagai suatu upaya pemberdayaan lahan kering dan lahan kritis.

Sorgum merupakan salah satu tanaman serealia yang cukup potensial untuk dikembangkan di Indonesia karena mempunyai daya adaptasi lingkungan yang cukup luas. Biji sorgum dapat diolah menjadi berbagai jenis makanan, sebagai bahan pakan ternak, dan sebagai bahan baku industri [5].

Salah satu jenis komoditas hasil pertanian yang potensial untuk dikembangkan sebagai bahan baku bioethanol di Indonesia adalah tanaman sorghum. Sorhgum sangat cocok untuk lahan lahan kering yang saat ini belum terolah dengan baik. Selain biji sorghum yang mempunyai kandungan karbohidrat yang tinggi, batang sorghum juga mengandung kadar gula yang tinggi. Sorghum sangat potensial untuk dikembangkan sebagai bahan baku pembuatan bioethanol karena beberapa alasan, diantaranya adalah proses perawatan yang minim, produktifikas yang tinggi serta mempunyai kemampuan adaptasi yang luas dibandingkan tanaman penghasil bioethanol lainnya [6].

Prospek penggunaan shorgum menjadi bahan baku pembuatan bioethanol sudah banyak diteliti sebelumnya telah melakukan review mengenai prospek pengembangan shorgum sebagai bahan baku pembuatan bioethanol [7].

Efisiensi produksi bioethanol masih menjadi kendala yang dihadapi oleh industri bioethanol. Sorghum merupakan salah satu komoditas yang sangat potensial untuk dikembangkan sebagai bahan baku bioethanol, namun sampai saat ini belum dapat diketahui tingkat efisiensinya. Dalam penelitian ini perumusan masalah yang akan diteliti adalah berapa tingkat efisiensi proses produksi bioethanol dari bahan bakan sorghum dengan menggunakan distilator refluk bertingkat, bagaimana pengaruh perubahan lama fermentasi terhadap kadar dan volume bioethanol yang dihasilkan.

Teknologi pada proses distilasi talah mengalami perkembangan dari tahun ke tahun. Saat ini dikembangkan alat distilator bioethanol sistem refluk bertingkat dengan spesifikasi sebagai berikut: diameter tangki $400 \mathrm{~mm}$, tinggi tangki $500 \mathrm{~mm}$, terbuat dari bahan stainles steel A304 dengan ketebalan 2 $\mathrm{mm}$. Kapasitas tangki yang diijinkan adalah $3 / 4$ dari volume tabung atau sebesar 40 liter. Dari hasil uji coba pada hasil proses distilasi fermentasi ketela pohon menunjukkan kadar tertinggi yang dapat dihasilkan dari mesin distilasi bioethanol dengan sistem refluk bertingkat ini adalah 92\%..[8] Peralatan tersebut sudah digunakan untuk menguji kadar ethanol yang dihasilkan dari tetes tebu. Dari hasil uji coba pada hasil proses distilasi fermentasi tetes tebu menunjukkan bahwa pada jenis fermenter enzim, npk, urea, ragi menunjukkan hasil yang paling baik. Dari hasil uji coba pada hasil proses distilasi fermentasi 
tetes tebu menunjukkan bahwa pada proses fermentasi selama 36 jam menunjukkan hasil yang paling baik.[9]

Proses penting lainya yang diperlukan untuk maningkatkan kadar ethanol adalah proses dehidrasi. Saat ini telah dikembangkan alat dehydrator bioethanol dengan spesifikasi diameter tangka $300 \mathrm{~mm}$, tinggi tangki $250 \mathrm{~mm}$, terbuat dari bahan stainles steel A304 dengan ketebalan $2 \mathrm{~mm}$. Bagian tabung I terbuat dari pipa stainless steel dengan diameter $100 \mathrm{~mm}$ dan tinggi $600 \mathrm{~mm}$. Tebal dari pipa tersebut adalah $2 \mathrm{~mm}$. Tabung II terbuat dari stainless steel yang mempunyai diamater $100 \mathrm{~mm}$ dan tinggi $300 \mathrm{~mm}$ dengan ketebalan $2 \mathrm{~mm}$. Kondensor dirancang berdiameter $100 \mathrm{~mm}$ dan tinggi $600 \mathrm{~mm}$. Berdasarkan hasil pengujian yang dilakukan menunjukkan bahwa mesin dehydrator tersebut mampu menghasilkan bioethanol berkadar $99,72 \%$ [10].

\section{METODOLOGI PENELITIAN}

Berdasarkan pendekatannya penelitian yang dilakukan ini adalah penelitian kuantitatif karena menggunakan rancangan penelitian eksperimental yang dilakukan dilaboratorium. Adapun beberapa tahapan penelitian dapat dijelaskan sebagai berikut:

\subsection{Tahap Persiapan}

Tahap ini dimulai dengan proses pengumpulan data tentang bahan pembuatan bioetanol yaitu sorghum merah dan sorghum putih dan mempelajari proses pembuatannya berdasarkan referensi yang tersedia. Setelah data terkumpul dilanjutkan dengan proses penentuan alat dan bahan yang akan digunakan. Dimana untuk jenis bahan baku sorghum putih dapat dilihat pada Gambar 1 dan bahan baku sorghum merah pada Gambar 2.

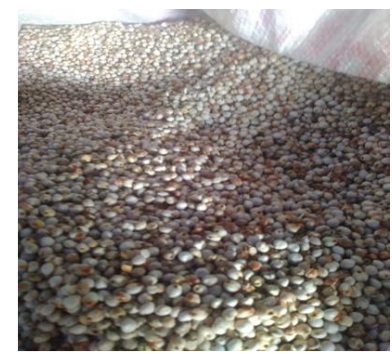

Gambar 1. Bahan Baku Sorghum Putih

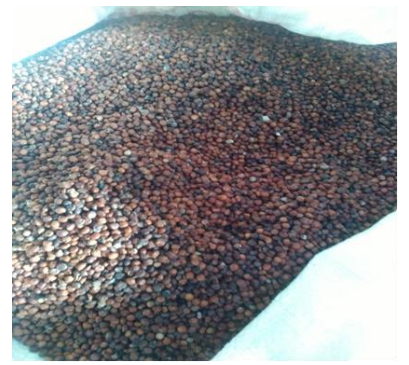

Gambar 2. Bahan Baku Sorghum Merah

\subsection{Tahap Pelaksanaan}

Tahap pelaksanaan dimulai dengan persiapan alat yang digunakan, pembersihan bahan baku, pengolahan menjadi tepung, proses fermentasi, proses distilasi dan proses dehidrasi.

\subsubsection{Tahap Fermentasi}

Tahap Fermentasi dilaksanakan dengan langkah langkah sebagai berikut: Menghaluskan biji sorghum hingga menjadi bubuk. Sorghum yang telah di haluskan selanjutnya ditambahkan air bersih sebanyak 15 liter (1,5 X berat bahan baku) dan diaduk hingga merata. Memasukan bahan baku kedalam coocker tank berupa drum kecil dan selanjutnya dimasak sampai mendidih. Mengaduk adonan sorghum yang dimasak hingga adonan mengental seperti Jelly dan mulai terasa berat ketika diaduk (proses gelatinasi). Melakukan pengecekan suhu adonan bubur sorghum menggunakan termometer celup. 
Apabila suhu adonan sudah mencapai $80^{\circ}-85^{\circ} \mathrm{C}$ masukan $10 \mathrm{ml}$ Enzym Alfa Amylase sambil terus diaduk sampai adonan berubah menjadi lebih cair seperti sup dan terasa ringan ketika diaduk

\subsubsection{Tahap Distilasi}

Distilasi atau lebih umum dikenal dengan istilah Penyulingan dilakukan untuk memisahkan alkohol dari cairan beer hasil fermentasi. Dalam proses distilasi, pada suhu $78^{\circ} \mathrm{C}$ (setara dengan titik didih alkohol) ethanol akan menguap lebih dulu dibandingkan dengan air yang bertitik didih $100^{\circ} \mathrm{C}$. Uap ethanol didalam distillator akan dialirkan kebagian kondensor sehingga terkondensasi menjadi cairan ethanol. Kegiatan penyulingan ethanol merupakan bagian terpenting dari keseluruhan proses produksi bioethanol. Proses destilasi dilaksanakan dengan menggunakan mesin distilator refluk bertingkat sebagaimana gambar 3 .

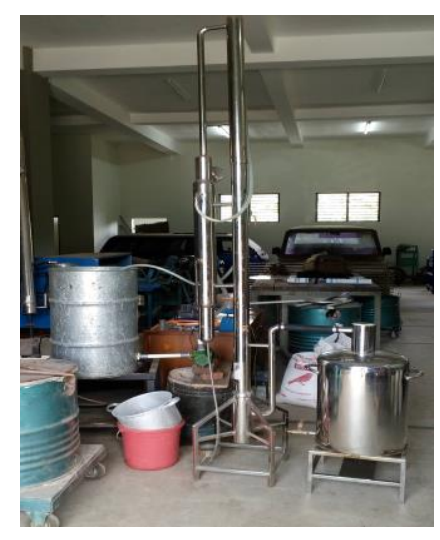

Gambar 3. Proses Destilasi

\subsubsection{Tahap Dehidrasi}

Proses dehidrasi dilakukan dengan tahapan sebagai berikut: memasang regulator gas elpiji dan memastikan tidak ada kebocoran gas. Setelah itu memasang selang "Atas" dari tabung kondensor ke output pompa air. Memasang dan menempatkan selang "Bawah" diatas drum plastik dekat pompa air. Dilanjutkan dengan membuka kran pada pompa air, lalu menyalakan pompa. Membiarkan air mengalir dari drum ke kondensor dan balik lagi ke drum. Setelah itu mematikan kran,s ampai pompa mati dengan sendirinya (otomatis). Pastikan tidak ada kebocoran air pada tiap sambungan selang di tabung kondensor. Memasukan 2 liter bahan ethanol kadar 88-90 \% (sesuai variabel) ke dalam tangki, lalu menutup kencang menggunakan kunci pengencang. Menyalakan kompor, untuk awal pemanasan agak besar apinya. Selang 15-20 menit, ketika jarum termometer"B" mulai naik, segera kecilkan api kompor, lalu buka kran pompa air 1/2 sampai 3/4-nya. Ethanol akan mulai keluar dari output tabung kondensor, mempertahankan posisi suhu pada termometer atas $65^{\circ} \mathrm{C}$. Proses dehidrasi menggunakan dehydrator tipe bath ditunjukkan pada gambar 4.

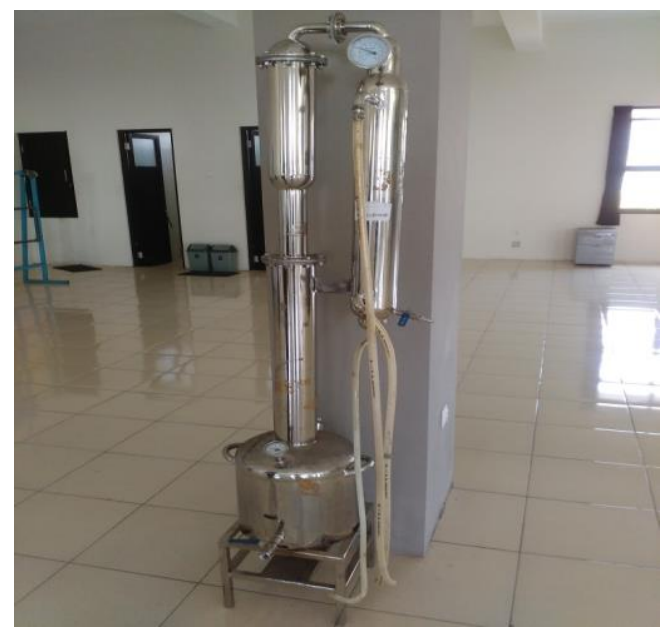

Gambar 4. Proses Dehidrasi 


\subsection{Tahap Pengujian}

Tahap pengujian terdiri atas proses pengujian bioethanol tahap 1 dan proses pengujuan kadar bioethanol tahap 2. Proses pengujian kadar bioethanol tahap 1 bertujuan untuk menguji kadar bioethanol hasil dari proses distilator, sedangkan proses pengujian kadar bioethanol tahap 2 bertujuan untuk mengetahui persentasi kadar bioethanol hasil dari proses dehidrasi.

\section{HASIL DAN PEMBAHASAN}

Pengujian dilaksanakan dengan memberikan variabel yaitu jenis sorghum yang digunakan yaitu sorghum merah dan sorghum putih. Setiap variabel dilaksanakan sebanyak 3 kali pengujian. Berdasarkan pengujian yang dilaksanakan didapat data sebagaimana Tabel 1 sd Tabel 4.

Tabel 1. Data hasil pengujian pengaruh waktu destilasi terhadap kadar ethanol dari bahan baku sorghum merah

\begin{tabular}{cccc}
\hline \multirow{2}{*}{ Pengujian ke } & \multicolumn{3}{c}{ Kadar(\%) } \\
\cline { 2 - 4 } & $\mathbf{3 0}$ menit & $\mathbf{6 0}$ menit & $\mathbf{9 0 ~}$ menit \\
\hline I & $85 \%$ & $78 \%$ & $72 \%$ \\
II & $85 \%$ & $80 \%$ & $75 \%$ \\
III & $86 \%$ & $78 \%$ & $72 \%$ \\
Rata - rata & $\mathbf{8 5 \%}$ & $\mathbf{7 9 \%}$ & $\mathbf{7 3 \%}$ \\
\hline
\end{tabular}

Dari Tabel 1 didapatkan data bahwa untuk pengujian kadar ethanol dengan bahan baku sorghum merah dengan pengujian waktu destilasi yang berbeda menghasilkan kadar ethanol yang berbeda juga. Dimana untuk lama waktu destilasi 30 menit menghasilkan kadar ethanol sebesar 83\%, kemudian saat waktu destilasi yang digunakan selama 60 menit kadar ethanol yang dihasilkan menurun yaitu sebesar $79 \%$ dan pada pengujian terakhir dengan menggunakan waktu destilasi selama 90 menit menghasilkan kadar ethanol yang semakin menurun sebesar 75\%. Dari data yang didapatkan diketahui bahwa semakin lama waktu destilasi yang digunakan, maka kadar ethanol yang dihasilkan pun semakin menurun. Dengan selisih waktu yang digunakan yaitu antara satu pengujian dengan pengujian lain sekitar 30 menit, memiliki selisih kadar ethanol atau penurunan kadar ethanol sebesar $6 \%$.

Tabel 2. Data hasil pengujian pengaruh waktu destilasi terhadap volume hasil ethanol dari bahan baku sorghum merah

\begin{tabular}{cccc}
\hline \multirow{2}{*}{ Pengujian ke } & \multicolumn{3}{c}{ Volume $(\mathbf{m l})$} \\
\cline { 2 - 4 } & $\mathbf{3 0}$ menit & $\mathbf{6 0}$ menit & $\mathbf{9 0}$ menit \\
\hline I & 700 & 380 & 250 \\
II & 650 & 480 & 250 \\
III & 650 & 380 & 240 \\
Rata - rata & $\mathbf{6 6 7}$ & $\mathbf{4 1 3}$ & $\mathbf{2 4 7}$ \\
\hline
\end{tabular}

Dari Tabel 2 didapatkan hasil perbandingan antara waktu destilasi yang digunakan dengan volume ethanol yang dihasilkan pada bahan baku sorghum merah. Pengujian dilakukan dengan selang waktu 30 menit. Dari penggunaan waktu destilasi selama 30 menit menghasilkan volume ethanol sebanyak $667 \mathrm{ml}$, kemudian saat waktu destialsi yang digunakan selama 60 menit menghasilkan volume ethanol sebanyak $413 \mathrm{ml}$ dan pada pengujian terakhir dengan waktu detilasi 90 menit menghasilkan volume ethanol sebanyak $247 \mathrm{ml}$.

Tabel 3. Data hasil pengujian pengaruh waktu destilasi terhadap kadar ethanol dari bahan baku sorghum putih

\begin{tabular}{cccc}
\hline \multirow{2}{*}{ Pengujian ke } & \multicolumn{3}{c}{ Kadar(\%) } \\
\cline { 2 - 4 } & $\mathbf{3 0}$ menit & $\mathbf{6 0}$ menit & $\mathbf{9 0 ~}$ menit \\
\hline I & $84 \%$ & $70 \%$ & $20 \%$ \\
II & $82 \%$ & $73 \%$ & $30 \%$ \\
III & $82 \%$ & $68 \%$ & $50 \%$ \\
Rata - rata & $\mathbf{8 3 \%}$ & $\mathbf{7 0 \%}$ & $\mathbf{3 3 \%}$ \\
\hline
\end{tabular}

Tabel 3 memperlihatkan hasil perbandingan antara pengaruh waktu destilasi yang digunakan dengan kadar ethanol yang dihasilkan menggunakan bahan baku sorghum putih. Pada pengambilan data dilakukan selang waktu antara pengujian satu dan yang lain selama 30 menit. Untuk waktu penggunaan 
pada proses destilasi selama 30 menit menghasilkan kadar ethanol sebesar $83 \%$, kemudian untuk proses destilasi selama 60 menit menghasilkan kadar ethanol sebesar $70 \%$ dan penggunaan waktu proses destilasi selama 90 menit menghasilkan kadar ethanol 33\%. Dari data didapatkan bahwa semakin lama waktu yang digunakan dalam proses destilasi ini memiliki pengaruh penurunan hasil dari kadar ethanol yang cukup signifikan.

Tabel 4. Data hasil pengujian pengaruh waktu destilasi terhadap volume hasil ethanol dari bahan baku sorghum putih

\begin{tabular}{cccc}
\hline \multirow{2}{*}{ Pengujian ke } & \multicolumn{3}{c}{ Volume $(\boldsymbol{m l})$} \\
\cline { 2 - 4 } & 30 menit & $\mathbf{6 0}$ menit & $\mathbf{9 0}$ menit \\
\hline I & 530 & 220 & 130 \\
II & 450 & 255 & 120 \\
III & 550 & 250 & 120 \\
Rata - rata & $\mathbf{5 1 0}$ & $\mathbf{2 4 2}$ & $\mathbf{1 2 3}$ \\
\hline
\end{tabular}

Tabel 4 memperlihatkan data hasil perbandingan antara kondisi lama tidaknya proses waktu destilasi dengan volume ethanol yang dihasilkan dari pemanfaatan bahan baku sorghum putih. Dari data didapatkan bahwa antara lama waktu proses destilasi dengan banyak volume ethanol yang dihasilkan memiliki hubungan linier turun, dimana semakin lama waktu yang digunakan pada proses destilasi maka volume ethanol yang dihasilkan semakin berkurang.

\section{KESIMPULAN}

Dari penelitian yang telah dilakukan didapatkan hasil bahwa:

a) Proses destilasi mempengaruhi hasil dari kadar ethanol dan volume ethanol untuk kedua jenis bahan baku, baik bahan baku sorghum merah dan sorghum putih.

b) Semakin lama waktu yang digunakan dalam proses destilasi maka kadar ethanol yang dihasilkan semakin berkurang.

c) Semakin lama waktu yang digunakan dalam proses destilasi maka volume ethanol yang dihasilkan semakin menurun.

\section{DAFTAR PUSTAKA}

[1] Y. Joko Santoso, "Analisis Prakiraan Kebutuhan Energi Nasional Jangka Panjang Di Indonesia," 2009.

[2] A. Lubis, "Energi Terabrukan Dalam Pembangunan Berkelanjutan," J. Tek. Lingkung., vol. 8, no. 2, pp. 156-163, 2007.

[3] A. H. Erliza Hambali, Siti Mujdalifah, Teknologi Bioenergi. 2007.

[4] G. Puspitasari, D. Kastono, S. Waluyo, Sumarmo, and Karsono, "Pertumbuhan Dan Hasil Sorgum Manis (Sorghum Bicolor (L.) Moench) Tanam Baru Dan Ratoon Pada Jarak Tanam Berbeda Growth," p. 12, 2012.

[5] M. P. Sirappa, "Prospek Pengembangan Sorgum di Indonesia sebagai Komoditas Alternatif untuk Uangan, Pakan, dan Industri," J. Litbang Pertan., vol. 22, no. 4, pp. 133-140, 2003.

[6] Sihono, M. I. Wijaya, and S. Human, "Perbaikan Kualitas Sorgum Manis Melalui Teknik Mutasi untuk Bioetanol,” pp. 978-979, 2010.

[7] A. Almodares and M. R. Hadi, "Production of bioethanol from sweet sorghum : A review," African J. Agric. Res., vol. 4, no. 9, pp. 772-780, 2014.

[8] R. Winarso, B. S. Nugraha, and T. Santoso, "Pengembangan Alat Destilator Bioetanol Model Refluk Bertingkat Dengan Bahan Baku Singkong,” J. SIMETRIS, vol. 5, no. 2, pp. 97-104, 2014.

[9] R. Winarso, B. S. Nugraha, A. Muttaqin, and N. Rofiudin, "Pengembangan Alat Destilator Bioetanol Sebagai Bahan Bakar Alternatif," Pros. SNST Fak. Tek. Univ. Wahid Hasyim Semarang, vol. 1, no. 1, pp. 7-12, 2016.

[10] R. Winarso and B. S. Nugraha, "Pengembangan Alat Dehydrator Bioetanol Model Bath," Pros. SNATIF, vol. 2, no. 1, pp. 435-440, 2015. 